\title{
Structural Investigations and Magnetic Properties of $\mathrm{BaFe}_{12} \mathrm{O}_{19}$ Crystals
}

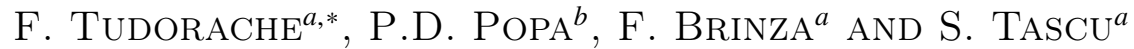 \\ ${ }^{a}$ Department of Physics, "Alexandru Ioan Cuza" University of Iasi, Blvd. Carol I, no. 11, 700506, Iasi, Romania \\ ${ }^{b}$ National Institute of R\&D for Technical Physics-IFT Iasi, Blvd. D. Mangeron, no. 47, 700050, Iasi, Romania
}

This work was dedicated to the preparation of a barium hexaferrite using the glass crystallization method. The glass flakes were treated at temperatures ranging between $550^{\circ} \mathrm{C}$ and $750^{\circ} \mathrm{C}$. The investigation carried out by X-ray diffraction revealed the phase composition and the mean crystallite size. By means of the scanning electron microscopy, the crystallite shape and average size were established. The electric and magnetic properties were investigated at room temperature by means of a Solartron 1260A impedance/gain phase analyzer and a vibrating sample magnetometer. The optimum heat treatment was established to obtain the maximum coercivity of the barium hexaferrite.

PACS: 75.75.Cd, 75.47.Lx

\section{Introduction}

The barium hexaferrite $\left(\mathrm{BaFe}_{12} \mathrm{O}_{19}\right)$ is known as a hard magnetic material and represents one of the mostly used materials in the area of magnetic recording media, which cannot be easily substituted by other magnets [1-3].

From the scientific point of view, as well as from the standpoint of the technological applications, the barium hexaferrite presents interest due to its special properties, such as: high remanence and coercivity, thermal, electrical and chemical stability $[4,5]$.

The maximum coercivity is obtained when the crystals have a maximal size, at which they remain single domains. The classical methods do not permit to prepare small enough monocrystals. One of the less studied methods is that of glass crystallization.

In this work we have prepared a barium hexaferrite using the glass crystallization method; the obtained glass flakes were then treated at different temperatures. The barium hexaferrite monocrystals resulting after the heat treatments were extracted by solving the matrix, and their structural, magnetic and electric properties were studied.

\section{Experimental methods}

The quantities of metal oxides $\mathrm{BaO}_{3}$ and $\mathrm{Fe}_{2} \mathrm{O}_{3}$ with $99 \%$ purity (Merck) were weighted according to the stoichiometric formula. The metal oxides were mixed together with $\mathrm{Sb}_{2} \mathrm{O}_{3}$ (99\% purity) and $\mathrm{B}_{2} \mathrm{O}_{3}$ (99.8\% purity) in proportion of 1:4, and then heated up to the melting

\footnotetext{
* corresponding author; e-mail: florin.tudorache@uaic.ro
}

point, to form the glass. In order to preserve the amorphous state, the glass melt was cooled down very fast, at a rate of $10^{4}$ degree/s, by pouring between two revolving copper cylinders, thus obtaining brown transparent glass flakes, with thickness of about $0.1 \mathrm{~mm}$.

The entire amount of glass flakes was divided in four equal parts, and calcinations were carried out in air for two hours each, at the following temperatures: $550^{\circ} \mathrm{C}$, $650^{\circ} \mathrm{C}, 700^{\circ} \mathrm{C}$ and $750^{\circ} \mathrm{C}$. After the calcinations treatment, the glass matrix was solved in an acid solution, and the resulted powder was washed with distilled water and prepared for investigations. The microstructure was investigated through X-ray diffraction, using a $\mathrm{Cu} K_{\alpha}$ anticathode and a scanning rate of $4 \mathrm{deg} / \mathrm{min}$ (Shimadzu LabX XRD-6000), as well as through electron microscopy (Quanta 200 3D).

In order to carry out electric investigations, the barium hexaferrite powder was uniaxially pressed in shape of disks with the diameter of $10 \mathrm{~mm}$ and the thickness of 2-3 mm. Silver electrodes were deposited on the both plane surfaces of the samples. The electric properties were investigated with the Solartron 1260A impedance/ gain phase analyzer within the frequency range $1 \div 10^{6} \mathrm{~Hz}$.

For magnetic measurements, spherical samples were prepared with diameters of 5-6 $\mathrm{mm}$. The measurements were carried out with a vibrating sample magnetometer at the temperature of $20^{\circ} \mathrm{C}$, in a field of $800 \mathrm{kA} / \mathrm{m}$.

\section{Results and discussion}

The analysis of the X-ray diffractograms from Fig. 1 shows that, in the case of the glass calcined for $2 \mathrm{~h}$ in air at the temperature of $550^{\circ} \mathrm{C}$, the generation of simple 
phases of hematite $\left(\mathrm{Fe}_{2} \mathrm{O}_{3}\right)$, magnetite $\left(\mathrm{Fe}_{3} \mathrm{O}_{4}\right)$ and barium ortho-ferrite $\left(\mathrm{BaFe}_{2} \mathrm{O}_{4}\right)$ occurs. Following the glass calcinations at $650^{\circ} \mathrm{C}$, one can notice that the magnetite disappeared, the amount of other simple phases diminished and the barium hexaferrite $\left(\mathrm{BaFe}_{12} \mathrm{O}_{19}\right)$ appeared. After $2 \mathrm{~h}$ calcination at the temperature of $750^{\circ} \mathrm{C}$, one can also notice the increase of the $\mathrm{BaFe}_{12} \mathrm{O}_{19}$ amount and of the particle size, as well as the diminution of the concentration of the $\mathrm{BaFe}_{2} \mathrm{O}_{4}$ and $\mathrm{Fe}_{2} \mathrm{O}_{3}$ simple phases.

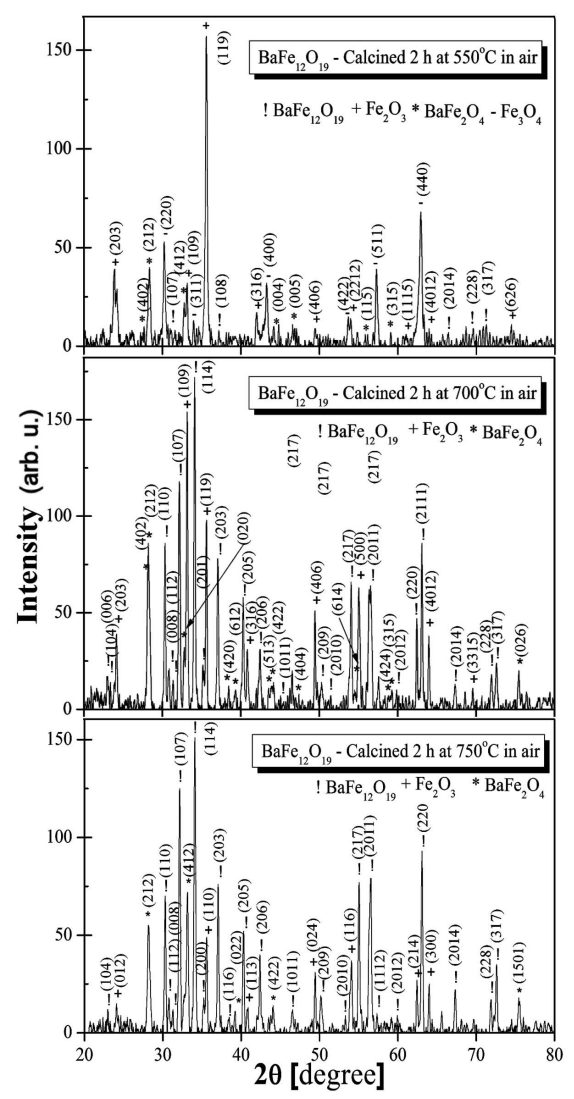

Fig. 1. X-ray diffraction patterns of barium hexaferrites samples.

The analysis of the SEM micrographs (Fig. 2) shows that, after the treatment at $550{ }^{\circ} \mathrm{C}$, small spherical crystallites appear, with the mean size of $0.2 \mu \mathrm{m}$. The calcination at $700{ }^{\circ} \mathrm{C}$ generates crystals with the mean size of $0.4 \mu \mathrm{m}$. After the calcination at $750^{\circ} \mathrm{C}$, the mean particle size, increases to $0.6 \mu \mathrm{m}$.

As the result of the performed electric investigations, presented in Fig. 3 and Table I, we concluded that all the samples of barium hexaferrite sintered at $700^{\circ} \mathrm{C}$ have conductivities of the order of $10^{-9} \mathrm{~S} / \mathrm{m}$ and small dielectric loss, and among them, the barium hexaferrite sintered at $700{ }^{\circ} \mathrm{C}$ presents the smallest value of the dielectric loss.

The measurements of saturation magnetization, residual magnetization and coercivity are presented in Table II. As the result of sintering in air for $2 \mathrm{~h}$ at $550{ }^{\circ} \mathrm{C}$, the sample resulted to be typical magnetically soft. It presents a high saturation magnetization $(38.3 \mathrm{emu} / \mathrm{g})$,
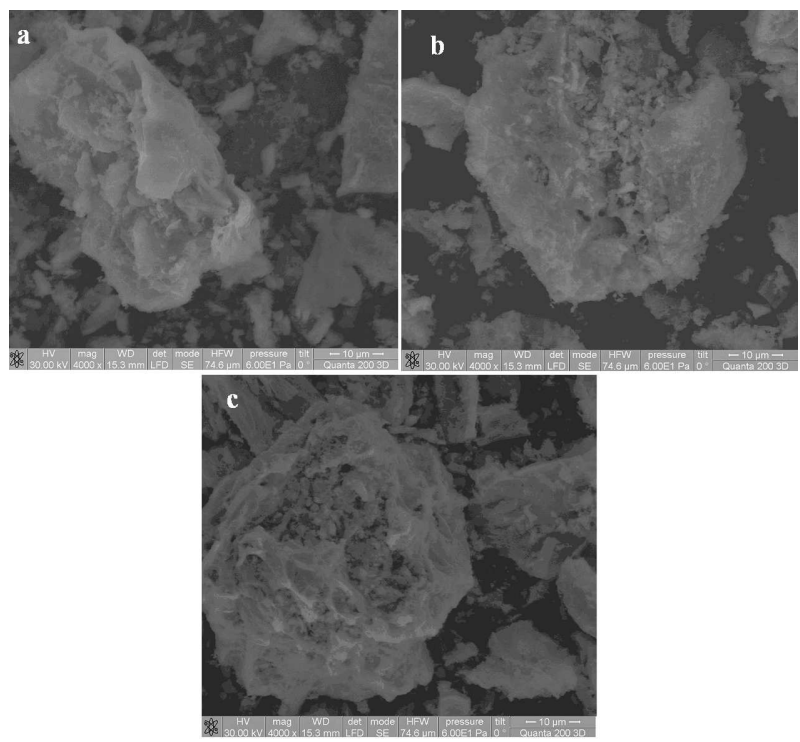

Fig. 2. SEM micrographs of $\mathrm{BaFe}_{12} \mathrm{O}_{19}$ calcined (a) $550^{\circ} \mathrm{C}$; (b) $700^{\circ} \mathrm{C}$ and (c) $750^{\circ} \mathrm{C}$.

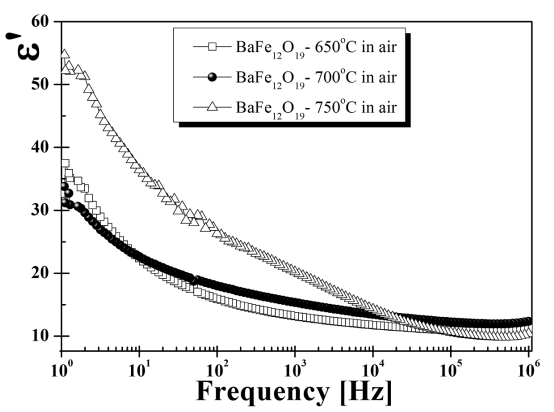

Fig. 3. Real part of permittivity vs. frequency at room temperature in $\mathrm{BaFe}_{12} \mathrm{O}_{19}$ hexaferrites.

a small residual magnetization and a very small coercivity. The calcination at $650^{\circ} \mathrm{C}$ results in a slight diminution of the saturation magnetization, a slight increase of the remanence and a notable increase of coercivity, from $14 \mathrm{kA} / \mathrm{m}$ to $331 \mathrm{kA} / \mathrm{m}$. A typical magnetic hard sample is obtained. The sample calcined at $700^{\circ} \mathrm{C}$ presents a slight increase of the saturation magnetization from $31 \mathrm{emu} / \mathrm{g}$ to $36 \mathrm{emu} / \mathrm{g}$, of the residual magnetiza-

TABLE I

Summary of the dielectrics characteristics of $\mathrm{BaFe}_{12} \mathrm{O}_{19}$ hexaferrites.

\begin{tabular}{c|c|c}
\hline \hline Sample & $\begin{array}{c}\text { Dielectric loss } \\
\text { low frequency } \\
{\left[10^{3} \mathrm{~Hz}\right]}\end{array}$ & $\begin{array}{c}\text { Conductivity } \\
{[\mathrm{S} / \mathrm{m}]}\end{array}$ \\
\hline calcined $2 \mathrm{~h}$ at $650^{\circ} \mathrm{C}$ in air & 0.11 & $2.65 \times 10^{-9}$ \\
calcined $2 \mathrm{~h}$ at $700^{\circ} \mathrm{C}$ in air & 0.10 & $1.52 \times 10^{-9}$ \\
calcined $2 \mathrm{~h}$ at $750^{\circ} \mathrm{C}$ in air & 0.20 & $2.07 \times 10^{-9}$
\end{tabular}


tion from $19 \mathrm{emu} / \mathrm{g}$ to $22 \mathrm{emu} / \mathrm{g}$, and of the coercivity from $331 \mathrm{kA} / \mathrm{m}$ to $360 \mathrm{kA} / \mathrm{m}$. The calcinations for $2 \mathrm{~h}$ at $750{ }^{\circ} \mathrm{C}$ results in a sample with the saturation and residual magnetization slightly higher, and the coerciv- ity slightly lower than for the sample calcined at $700^{\circ} \mathrm{C}$. The maximum $M_{\mathrm{S}} / M_{\mathrm{R}}$ ratio is equal to 0.61 and it is obtained at the sample calcined at $700^{\circ} \mathrm{C}$.

Summary of the magnetic properties of barium hexaferrites.

TABLE II

\begin{tabular}{c|c|c|c}
\hline \hline Sample & $\begin{array}{c}\text { Coercivity } \\
H_{\mathrm{c}}[\mathrm{kA} / \mathrm{m}]\end{array}$ & $\begin{array}{c}\text { Saturation } \\
\text { magnetization } \\
M_{\mathrm{S}}[\mathrm{emu} / \mathrm{g}]\end{array}$ & $\begin{array}{c}\text { Remanence } \\
M_{\mathrm{R}}[\mathrm{emu} / \mathrm{g}]\end{array}$ \\
\hline calcined $2 \mathrm{~h}$ at $550^{\circ} \mathrm{C}$ in air & 14.3 & 38.3 & 15.7 \\
calcined $2 \mathrm{~h}$ at $650^{\circ} \mathrm{C}$ in air & 331 & 31.4 & 18.8 \\
calcined $2 \mathrm{~h}$ at $700^{\circ} \mathrm{C}$ in air & 360 & 36.2 & 21.9 \\
calcined $2 \mathrm{~h}$ at $750^{\circ} \mathrm{C}$ in air & 320 & 38 & 22.8
\end{tabular}

\section{Conclusions}

Using the glass crystallization method, submicron crystals of barium hexaferrite were obtained through calcinations at a temperature exceeding $600^{\circ} \mathrm{C}$.

The highest values of the coercivity and of the $M_{\mathrm{S}} / M_{\mathrm{R}}$ ratio were obtained at the sample calcined for $2 \mathrm{~h}$ at $700^{\circ} \mathrm{C}$. This sample contains mostly barium hexaferrite crystals with the mean size of $0.4 \mu \mathrm{m}$; it has lower electric conductivity and dielectric loss than the samples calcined at other temperatures.

The barium hexaferrite powder obtained through crystallization in the glass matrix for $2 \mathrm{~h}$ at $700^{\circ} \mathrm{C}$ can be successfully used in magnetic memory media.

\section{Acknowledgments}

Authors are grateful to "Research Center on Advanced Materials and Technologies - RAMTECH" created within the framework 162/15.06.2010 of POS CCEA2-O2.1.2, where these measurements have been done.
Researches of Florin Brinza were supported by grant no. 72-191/2008 NUCNANO, MECTS-CNMP Romania.

\section{References}

[1] R. Nowosielski, R. Babilas, G. Dercz, L. Pajak, W. Skowronski, J. Achiev. Mater. Manufact. Eng. 27, 51 (2008).

[2] K. Brzózka, P. Sovák, B. Górka, T. Szumiata, M. Gawroński, Acta Phys. Pol. A 119, 33 (2011).

[3] K. Kouřil, V. Chlan, H. Štěpánková, A. Telfah, P. Novák, K. Knížek, Y. Hiraoka, T. Kimura, Acta Phys. Pol. A 118, 732 (2010).

[4] P. Xu, X. Han, M. Wang, J. Phys. Chem. C 111, 5866 (2007).

[5] M.P. Dasari, K. Sambasiva Rao, P. Murali Krishna, G. Gopala Krishna, Acta Phys. Pol. A 119, 378 (2011). 